\title{
研究課題別事後評価結果
}

1. 研究課題名：ヒューマノイドのための実時間分散情報処理

2. 研究代表者名及び主たる研究参加者名 (研究機関名・職名は研究参加期間終了時点)

研究代表者：松井 俊浩（(独)産業技術総合研究所デジタルヒューマン研究センター 副センター長)

主たる共同研究者：

山㟝 信行 （慶應義塾大学大学院理工学部 准教授）

石川 裕 (東京大学大学院情報理工学系研究科 教授)

比留川 博久（(独）産業技術総合研究所知能システム研究部門 副研究部門長）

3. 研究内容及び成果:

$3-1$. 研究実施の概要

ヒューマノイドロボットのような大規模で複雑なシステムの実現には、実時間制御機能と高い情 報処理性能の両立が必要である。従来のヒューマノイドロボットは、1-2 個のプロセッサによる集中 制御が行われているが、約 30 の関節プロセッサによる実時間・分散制御の実現によってこの課題 に挑戦する。本研究は、次の三つで構成する。(1)RMTP の開発: 害時間性にすぐれたマルチスレ ッドアーキテクチヤ、高並列のベクトルユニット、実時間通信チャネルを備えたプロセッサを作成す る、(2)実時間基盤ソフトウエア:Linux-2.6 を拡張して優先度に基づく実時間スケジューリングを 可能にし、プログラムの実行時間を静的に予測する技術を開発する、(3)ロボット実証: 認識、対話、 歩行、経路計画などの機能をモジュラーに構成することで分散化し、並列処理を活用して性能 向上を図る。プロセッサのマルチスレッド並列、ベクトル並列、分散処理によって、Pentium 級の 処理性能を低消費電力で実現する。プロセッサをセンサやアクチュエータの近くに配置することで、 信号線の延長を大幅に削減し、高い信頼性を実現する。分散制御のため、通信およびマルチス レッド実行を実時間化し、優先度や資源割り当て等を行う基盤ソフトウエアを開発する。これらの 技術をロボットに集積することで、高度で高信頼のロボット制御を実現する。

$3-2$. 成果

(1) 実時間・分散向きの新規なプロセッサアーキテクチャRMTP を設計し、システムオンチップとして試作した。 CPU とメモリを小型の SiP として実装し、Linux を動作させた。

(2) 実時間分散制御に必要な通信機能をResponsive Link として開発し、ISO/IEC-24740 として国際規格化 を達成した。

(3) Linux に実時間スケジューリング機能を実現した。各種のプロセッサとメモリモデルに基づいて $\mathrm{C} と \mathrm{C}++7 ゚$ ログラムに適用可能な WCET 解析ツールを開発した。

(4) ロボットの関節に分散させたノードをレスポンシブリンクで結合するアーキテクチャを提案し、体積比で従来 の $1 / 17$ の関節ノードモジュールを開発した。

3-3. グループごとの研究内容および成果

(1) RMT-LSI グループ (山㠃信行)

8 つのマルチスレッドの優先度スケジューリング、32 個のスレッドプール、256レジスタの整数およ 
び浮動小数ベクトルユニット、実時間ネットワークResponsive Link、ロボット制御向きの各種 IO を備えたプロセッサ、RMTP アーキテクチャ(図 1-1)を設計した。命令セットは、MIPS を元に、ス レッド制御、ベクトル命令を拡張している。特に小型の実装向きの $\mu \mathrm{RMTP}$ を $0.13 \mu \mathrm{m}$ スケール、 1400 万ゲート、1040 ピンのシステム LSI として試作した。さらに、各種のモジュールへの展開が 容易な小型 CPU モジュールとして、128MB のメモリと共に $33 \mathrm{~mm}$ 角の SiP (system in package）として実装した。また、より高性能の応用向きにメモリバス幅が大きく、クロック当たりの 命令実行数をフィードバック制御できるような HP-RMTP の設計を行った。 $\mu$ RMTP は、 $33 \mathrm{MHz}$ （設計クロックは $100 \mathrm{MHz}$ ）動作時の消費電力が $1 \mathrm{~W}$ 以下であった。

実時間ネットワークである Responsive Link は、優先度付きルーティング、優先 度によるパケット追い越し、エラー訂正、2 重リンクをハードウエアで実現している。デ バイスインタフェース用のネットワークとして ISO/IEC において ISO 24740 として国 際標準規格化した。

（2）基盤ソフトウェアグループ(石川裕)

RMTP の命令レベルシミュレータを開発 し、Linux-2.6 の移植を行い、最終的に $\mu \mathrm{RMTP}$ で動作することを確認した。 i386 アーキテクチャ用の Linux に改造を

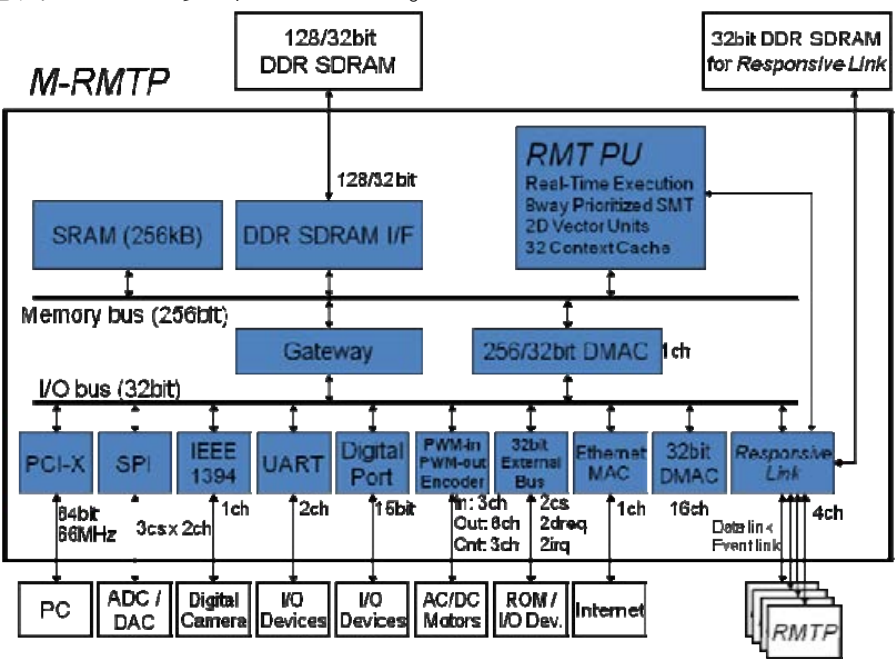

図 1-1 M-RMTP のブロック図 加え、特にロボットで重要な周期タスクを短周期で正確に実行するための実時間スケジューラを 開発した。この実時間 Shi-Linuxを用いて実ヒューマノイドのモータを取り出した分散モータテスト ベンチで性能評価を行い、最大 $30 \mu$ 秒の誤差で制御できることを確認した。

ロボットプログラムのより正確な実時間保証を目的として、GCC を元にして、プログラム(関数)の 最悪実行時間 (WCET)を予測するコンパイラを開発した。サーボタスクをベンチマークにして、実 際の実行時間の $200 \%$ 予測が得られた。実際のプログラムは最悪のパスではないこと、評価に 用いた Pentium プロセッサのキャッシュメモリの動作が不確定であることを考慮すると、合理的か つ有用な結果である。RMTP のような明解なプロセッサでは、より高精度の予測が得られると期待 できる。

(3) ロボット実証グループ(松井俊浩・比留川博久)

RMTP および実時間基盤ソフトウエアによってヒューマノイドロボットの分散制御を行うアーキテ クチャを検討した。ロボットの知的動作に必要な認識と動作計画機能には、十分な並列性があり、 低クロックのプロセッサの分散制御で性能向上が可能であること、安定な歩行の実時間制御には、 $5 \mathrm{~ms}$ の軌道生成と $1 \mathrm{~ms}$ 周期のサーボが必要で、さらに短周期化できれば力制御も可能になると の知見が得られた。

関節に搭載し、数百 $\mathrm{W}$ の $\mathrm{AC} / \mathrm{DC}$ モータを制御するアンプを備えた $45 \mathrm{~mm}$ 角の小型の $\mathrm{RMTP}$ ノードを設計した。容積比で従来のモータ制御モジュールの $1 / 17$ を達成した。また、関節ノードを Responsive Link によって接続し、中央の制御コンピュータにインタフェースするための cPCI バ ス用の RMTP ボードを設計した。

ヒューマノイドロボットを安定に実時間制御するための Linux カーネルとして、ART-Linux を 
Linux-2.6に対応させるための改良を行った。ART-Linuxを用いて、産業技術総合研究所と川 田工業が開発した分散制御型 HRP-3 を歩行させる実験に成功した。

4. 事後評価結果

4-1. 外部発表(論文、口頭発表等)、特許、研究を通じての新たな知見の取得等の研究成果の状況

ジャーナル論文が和文11件、英文29件あり、国際会議も16件、口頭発表64件、招待講演 14 件あるので、こ の分野では十分な数の発表を行ったといえる。また、受賞が16件あり、この研究が優れた成果を挙げ、分野をリ ードしていることを示している。

特許の出願は国内8件、国際4件である。国内では、プロセッサ関係と通信方式、マルチタスク処理方式など の特許が出されており、国際特許はすべてプロセッサ関係である。これらの出願はすべて、システムの基本的な 方式関連である。ソフトウエア関係にもオリジナルなアイデアがあるが、それはオープンソースの Linuxをベース としているので知財登録は馴染まず、出願は行われていない。また、Responsive Link の方式と実装は、 ISO/IEC-JTC1 SC25 に国際標準提案が行われ、2007 年にISO-24740 として国際標準化が確定した。以上 から、知財に関して十分な出願が為されているといえよう。

成果といら面から見ると、実時間制御用プロセッサとして優れた性能を出すために優位性のある研究成果が 得られている。プロセッサ LSI の実際の製作に関しては、論理検証が不十分であったため再試作が必要となり、 また小さなシステムボードとしての SiP(System-in-Package) 実装を試み最先端の実装をおこなったため、予期 できない障害が発生し、最終のデモシステムにまでは繋がらなかった。ソフトウエアに関しては、実時間用 Linux カーネルを提案し、100 $\mu \mathrm{s}$ 周期のサーボが安定して実行できるといら優れた性能を示すとともに、実時 間処理の詳細な解析技術 WCET もオリジナルで優れた研究成果となっている。

以上から、研究成果は十分あるが、最終デモに繋がらなかったのが惜しまれる。

論文、受賞、特許、招待講演など、多くの成果を出しており、当初計画の大多数を達成していると言えよう。し かしながら、当初計画は、これらの研究成果の下、プロセッサRMTP と微小実装 $\operatorname{SiP}$ を使って、実際にデモ用ロ ボットを作成するといらことを挙げていたが、RMTP を仕様通りに動作させることと SiP 実装に時間がかかり、最 終の完全なデモまで至らなかった。それから見ると、完全とは言い難い。とはいえ、この目標自体が、大学や産 総研のような基礎研究機関には大きすぎたと見ることも出来よう。現在の複雑なチップを完成させるということは、 大変大きな仕事であり、専門企業において膨大なコストを掛けて何度もの手直しを必要とするのが通常だからで ある。

一方、他の技術要素である実時間カーネルについては、優れた特性を持つといら評価がなされており、また 実時間の詳細な解析技術 WCET もオリジナルで優れた研究成果となっている。

\section{$4-2$. 成果の戦略目標・科学技術への貢献}

実時間制御用プロセッサのアーキテクチャを示し、実時間処理の解析手法を与え、ロボット制御に対する分 散アーキテクチャのあり方を示したことは科学的に大きなインパクトを与えたといえる。また、最新の SiP 実装を卜 ライし、その可能性を示すことで技術的なインパクトを与えた。それらを融合してデモするところまで達成すれば、 誰にでも分かりやすい大きなインパクトになったであろう。

国内・国外を問わず、厳しい今後に求められる実時間制御を可能にするロボット技術を、プロセッサから OS、 実装まで一貫しておこなっているプロジェクトは、これ以外に存在しない。従って、この成果は明らかに世界で卜 ップレベルにある。また、その重要な要素技術の一つ Responsive Link が国際標準になったことは、この技術 
が、他の通信技術に比して飛びぬけて優れた性能を有することの証明でもある。更に、実時間カーネルと解析 技術 WCET の技術は、ロボットのみならず、他の実時間制御で十分通用する優れた技術である。

これらの技術を使って様々な実装が行われれば、その利用価值が広く明らかになり、更に発展する可能性が ある。特に、Responsive Link や実時間カーネルは、広く使われる可能性がある。一方、プロセッサ技術に関し ては、商用のCore2 などに比して、明らかに方式上の優位性を有するが、それだけでは広く使われるとは限らな い。プロセッサの系列を継続的に開発してゆく体制が伴わない限り、面白い技術に留まる可能性が高い。しかし、 組み込みチップベンダーがこの優位性を取り入れることがあれば、大変大きな展開となる可能性がある。

4-3. その他の特記事項(受賞歴など)

この研究では、ロボットの分散制御の通信リンク方式として Responsive Link を標準化し、それがISO/IEC 24740 といら国際標準となっている点が特筆される。これらは標準化貢献賞や国際標準化奨励者表彰、国際規 格開発賞などの受賞になって表れている。

受賞に関しては、論文賞 2 件、学生奨励賞 1 件、標準化関係 3 件、他プレゼンテーション賞など 10 件、併せ て 16 件である。 